\title{
Inter-annual fluctuations of zooplankton communities in the Bay of Villefranche-sur-mer from 1995 to 2005 (Northern Ligurian Sea, France)
}

\author{
P. Vandromme ${ }^{1,3}$, L. Stemmann ${ }^{1}$, L. Berline ${ }^{1,4}$, S. Gasparini ${ }^{1}$, L. Mousseau ${ }^{1}$, F. Prejger ${ }^{1}$, O. Passafiume ${ }^{2}$, \\ J.-M. Guarini ${ }^{5,6}$, and G. Gorsky ${ }^{1}$ \\ ${ }^{1}$ LOV, Observatoire Océanologique, UMR7093, UPMC Univ Paris 06, 06234, Villefranche/mer, France \\ ${ }^{2}$ OOV, Observatoire Océanologique, UMS829, UPMC Univ Paris 06, 06234, Villefranche/mer, France \\ ${ }^{3}$ IFREMER, Centre Bretagne, Département Dynamique de l'Environnement Côtier (DYNECO), B.P. 70, \\ 29280, Plouzané, France \\ ${ }^{4}$ CNRS, UMR6017, LSEET, Université du Sud Toulon-Var, B.P. 132, 83957, La Garde cedex, France \\ ${ }^{5}$ UPMC Univ Paris 06, Océanographie, Environnements Marins, 4 Place Jussieu, 75005 Paris, France \\ ${ }^{6}$ CNRS, INstitute Environment Ecology, INEE, 3 Rue Michel-Ange, 75016 Paris, France
}

Received: 8 November 2010 - Published in Biogeosciences Discuss.: 15 December 2010

Revised: 17 October 2011 - Accepted: 21 October 2011 - Published: 7 November 2011

\begin{abstract}
An integrated analysis of the pelagic ecosystems of the Ligurian Sea is performed combining time series (1995-2005) of several zooplankton groups (one group for copepods smaller than $0.724 \mathrm{~mm}^{3}$ and nine groups for individuals larger than $0.724 \mathrm{~mm}^{3}$, i.e. large copepods, decapod larvæ, other crustaceans, chaetognaths, appendicularians, pteropods, thaliaceans, gelatinous predators and other zooplankton), chlorophyll- $a$, nutrients, salinity, temperature, density, and local weather at Point B coastal station (Northern Ligurian Sea). From 1995 to 2000 winters were wet and mild resulting in lower winter sea surface density. These years showed lower than average nutrients and zooplankton concentrations while chlorophyll- $a$ biomass was high. After 2000, winters were colder and dryer resulting in higher sea surface density. Nutrients and zooplankton showed higher concentrations while chlorophyll- $a$ was lower than average. The ca. 2000 change was observed for most zooplankton groups with a one-year delay for some groups. Inter-annual variability within each period was also observed. The observed patterns suggest that the pelagic ecosystem trophic state at the studied point is mostly set by the winter forcing on the vertical mixing that upwells nutrients to the surface sustaining primary production. Surprisingly, low chlorophyll- $a$ biomass in high nitrate and zooplankton conditions during the well mixed years suggest that phytoplankton biomass is
\end{abstract}

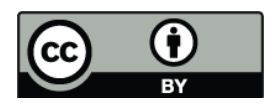

Correspondence to: P. Vandromme (vandromme.pieter@gmail.com) controlled by grazers. The proposed mechanisms of stronger winter vertical mixing hold for most of the time series, but specific years with contradicting patterns suggest also the possible influence of the summer climate. A review of recent literature suggests that changes in the pelagic ecosystem are not limited to the studied site but concern also the central Ligurian Sea.

\section{Introduction}

Plankton, because of their rapid response to ecosystem variability, their non-exploitation as commercial species and their amplification of subtle changes through non-linear processes, have been suggested to be indicators of climate variability (Taylor et al., 2002; Perry et al., 2004; Hays et al., 2005). Notably, the use of long-term plankton time-series can be a key tool to detect those changes (Perry et al., 2004; Alheit and Bakun, 2010; Mackas and Beaugrand, 2010). Recently, temperature changes have been suggested to cause regime shifts in pelagic ecosystems. For example, in the Atlantic Ocean, a regime shift from cold to warm biotopes, with a turning point in 1987, has been described and linked to the North Atlantic Oscillation (NAO), and to surface temperature anomalies in the Northern Hemisphere (NHT, Reid et al., 2001, 2003; Beaugrand, 2004). However, in semi enclosed seas and highly populated regions such as the Baltic Sea, shifts in the pelagic ecosystem state have been primarily

Published by Copernicus Publications on behalf of the European Geosciences Union. 
attributed to direct human impact (overfishing, eutrophication) while climate may have more influenced timing, magnitude and persistence (Österblom et al., 2007).

Regarding Mediterranean plankton, very few studies on long-term variation have been conducted due to the paucity of long-term time series (Mazzocchi et al., 2007). The possible appearance of a regime shift with a turning point in 1987 has been proposed in two northern Mediterranean coastal ecosystems (Adriatic and Ligurian Sea, Conversi et al., 2010). The authors pointed out the synchrony between changes in the Mediterranean sea and the north, Baltic and Black seas. The authors suggested the positive trend of surface temperature in the northern hemispheres as the main forcing for the concomitant changes in such remote and diverse locations. From a joint study of six zooplankton time series in the Mediterranean Sea, changes in zooplankton community were also observed in a third Mediterranean area, the Thyrreanean Sea, in addition to changes in the Adriatic and Ligurian seas, with again, a main turning point in 1987 (Berline et al., 2011). The detailed analysis of a long time series (1967-1993) in the Ligurian Sea suggested that the pelagic ecosystem was heading toward a more regenerated system after 1987 in which jellyfish controlled copepods by predation and chaetognaths by competition (Molinero et al., 2005, 2008). However, a more recent study from the same time series extended until 2003 revealed that the zooplankton and mainly copepods recovered to almost their initial concentrations after 2000 suggesting a quasi decadal cycle instead of a long term change (Garcia-Comas et al., 2011). Higher abundance of zooplankton in the ' 80 s and late ' 90 s in the Ligurian sea was correlated with dry and cold winters, resulting in high winter mixing enhancing nutrients replenishment and possibly strengthening the spring bloom. Diverse zooplankton taxa (copepods, decapod larvæ, chaetognaths, siphonophores, medusæ) showed quasi synchronous changes suggesting that the whole zooplankton community was controlled by its resources. This hypothesis of a "bottom-up" control initiated by the intensity of the winter vertical mixing is also supported by several observations in the southern and central Ligurian Sea (Goffart et al., 2002; Nezlin et al., 2004; Marty and Chiavérini, 2010), with no consideration of the zooplankton. The contrasting results show that the identification of regime shifts in North Western Mediterranean pelagic ecosystems is a difficult task requiring the acquisition of multiple long time series of physical, biogeochemical and planktonic data.

The aims of the present work are (i) to confirm the zooplankton recovery in the late ' 90 s by using an independent zooplankton time series, (ii) to determine, by combining hydrology, nutrients, phytoplankton biomass and ten zooplankton groups, if changes were simultaneous across the pelagic ecosystem and (iii) to determine the main causes of inter-annual variability of zooplankton in the Ligurian Sea. Compared to those previous studies the present one is original regarding: (i) the use of the WP2 net which has a smaller mesh size $(200 \mu \mathrm{m})$ than previously used nets (JudayBogorov, $300 \mu \mathrm{m}$, used in Molinero et al., 2005, 2008; Garcia-Comas et al., 2011); this allows us to study a smallest fraction of copepods, known for their central role in Mediterranean pelagic ecosystems (Calbet et al., 2001; Gallienne and Robins, 2001; Siokou-Frangou et al., 2010). (ii) The concomitant analysis of weekly-sampled time series of local climate, hydrology, chemistry (nutrients), phytoplankton (chlorophyll-a) and zooplankton in the Ligurian Sea from 1995 to 2005. Zooplankton samples analysis was done using the ZooScan equipment (Gorsky et al., 2010). Abundance and biovolume for 10 zooplankton groups was calculated (small and large copepods, chaetognaths, appendicularians, pteropods, thaliaceans, decapod larvæ, other crustaceans, other gelatinous and other zooplankton).

\section{Materials and methods}

\subsection{Sampling site and environmental datasets}

The Bay of Villefranche-sur-Mer is located in the Northern part of the Ligurian Sea (NW Mediterranean Sea, Fig. 1). The monitored station, called Point B (Fig. 1), is located at the entrance of the Bay $\left(43^{\circ} 41.10^{\prime} \mathrm{N}, 7^{\circ} 18.94^{\prime} \mathrm{E} ; 85 \mathrm{~m}\right.$ water depth). All basic physical, hydrological, chemical and biological parameters have been sampled weekly since 1995. The environmental variables selected for the analysis are: nitrate $\left(\mathrm{NO}_{3} \mu \mathrm{mol} 1^{-1}\right)$, chlorophyll- $a\left(\mu \mathrm{g}^{-1}\right)$, sea water temperature $\left({ }^{\circ} \mathrm{C}\right)$, salinity (psu) and density $\left(\sigma_{\theta}\right)$, sea water stratification $\left(\Delta_{\text {density }} \mathrm{m}^{-1}\right.$ between $50 \mathrm{~m}$ and $10 \mathrm{~m}$ depth, i.e. (Dens. $50 \mathrm{~m}$-Dens. $10 \mathrm{~m}) / 40 \mathrm{~m}$ ), air temperature $\left({ }^{\circ} \mathrm{C}\right)$, precipitations $\left(\mathrm{mm} \mathrm{d}^{-1}\right)$, wind mean daily speed $\left(\mathrm{m} \mathrm{s}^{-1}\right)$ and irradiance $\left(\mathrm{J} \mathrm{cm}^{-2} \mathrm{~d}^{-1}\right)$. Water for nitrate and chlorophyll- $a$ analysis was sampled by Niskin bottles at 6 different depths, i.e. surface, $10,20,30,50$ and $75 \mathrm{~m}$ depth - depth averaged values ( $0-75 \mathrm{~m}$ depth) were used in our analysis. nitrate were analyzed by colorimetry (Aminot and Kérouel, 2004) with an autoanalyzer Technicon Alliance, chlorophyll- $a$ was determined by spectrometry and fluorimetry (Strickland and Parsons, 1977). A Seabird SBE25 CTD was used for weekly sea water temperature, salinity and density analysis of the water column. In the present work, temperature, salinity and density were averaged over the depth $(0-75 \mathrm{~m})$. All these environmental measurements fit the quality controls and protocols of SOMLIT (Goberville et al., 2010). Local weather was provided daily by Météo-France at a meteorological station, the Sémaphore, located on Cap-Ferrat at $138 \mathrm{~m}$ height and $1.2 \mathrm{~km}$ away from Point B.

\subsection{Zooplankton data}

The net samples used in this study were collected weekly from February 1995 until December 2005 aboard the $N O$ Sagitta and NO Vellele. Sampling was carried out vertically between $60 \mathrm{~m}$ and the surface with a WP2 net (mesh 


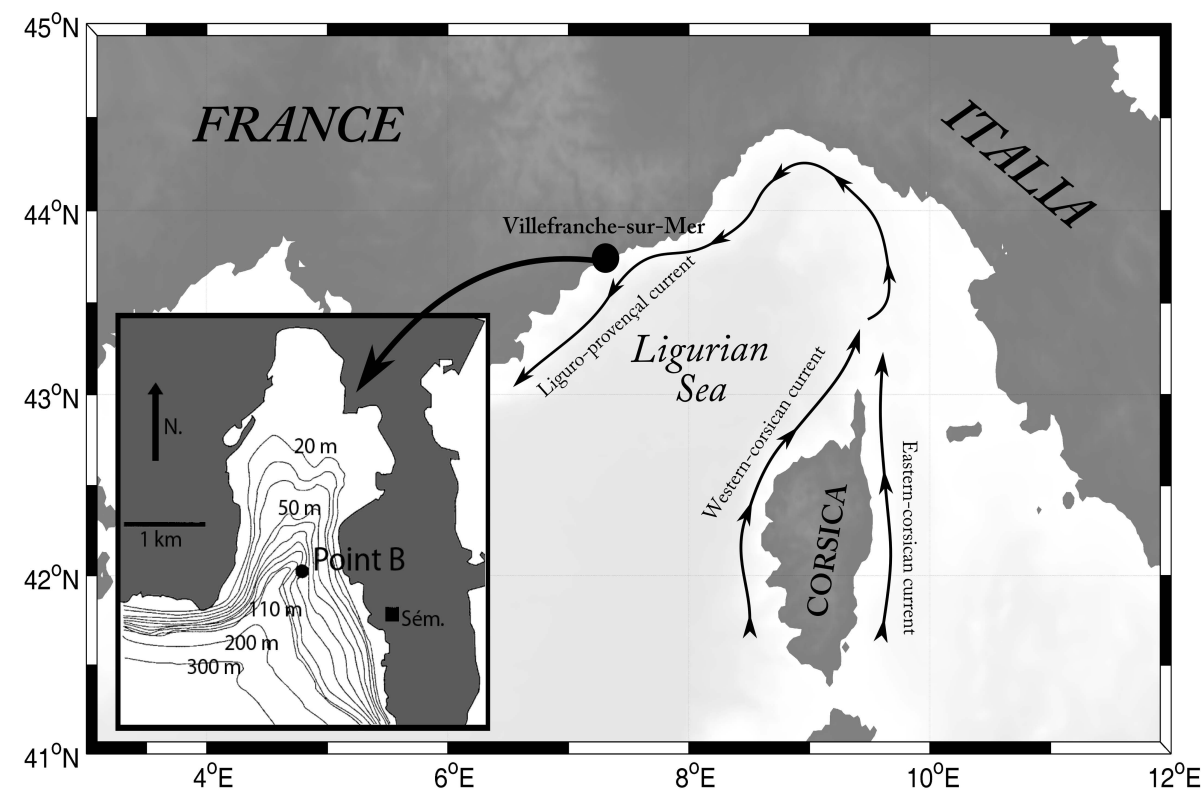

Fig. 1. Location of the sampling site (Pt. B) in the Ligurian Sea and the meteorological station Sémaphore (Sém.) situated in Cap Ferrat $1.2 \mathrm{~km}$ from Point B. The cyclonic circulation of the Ligurian Sea with the Liguro-Provençal Current, the Western Corsican Current and the Eastern Corsican Current are also shown on this map. The central zone of the Ligurian Sea is separated from more coastal areas by the frontal zone.

size of $200 \mu \mathrm{m}$, mouth aperture of $0.25 \mathrm{~m}^{2}$ ). The resulting time series included 489 samples (7-8 weeks were missing per year on average) and contained a total of $\approx 600000$ objects digitized with the ZooScan imaging system developed at the "Laboratoire d'Océanographie de Villefranchesur-mer" (Gorsky et al., 2010). The zooplankton sampling was carried out in the frame of the RADEZOO program.

Each sample was gently separated into two subsamples with a $1000 \mu \mathrm{m}$ mesh. Then each subsample was fractionated separately with the Motoda box in order to have an average of $\sim 1000$ objects per scan (Gorsky et al., 2010). Since small objects are generally more abundant than large ones, they were fractionated more. The separation of small and large objects and the subsequent separate image acquisition of the two-size classes prevents underestimation of large rare objects (Gorsky et al., 2010). Results from both fractions were then cumulated in the analysis. This procedure enables to quantitatively record objects larger than $0.032 \mathrm{~mm}^{3}$ which is equivalent to a spherical diameter larger than ca. $350 \mu \mathrm{m}$ (Vandromme, 2010). Images were analyzed by dedicated imaging software called ZooProcess (Gorsky et al., 2010). Several variables were measured from each extracted object such as "Major": primary axis of the best fitting ellipse for the object, and "Minor": secondary axis of the best fitting ellipse for the object. From the Minor and Major axes, an equivalent apparent elliptical biovolume (EBv) was estimated: $\mathrm{EBv}=4 / 3 \cdot \pi \cdot\left(\right.$ Major/2) $\cdot(\text { Minor } / 2)^{2}$. All other variables (see Appendix 4 in Gorsky et al., 2010) were utilized for the automatic classification of objects which was per- formed using the free software "Plankton Identifier" (Gasparini, 2007) based on Tanagra data mining software (Rakotomalala, 2005). The zooplankton was successfully separated from non-living objects with a recall rate of 0.94 and a contamination rate of 0.04 (see Gorsky et al., 2010, for definition of recall and contamination). However this is mainly due to the efficient classification of copepods (recall rate of 0.92 and contamination of 0.02 ). These rates decrease for large objects and a visual classification of all objects larger than $0.724 \mathrm{~mm}^{3}$ in $\mathrm{EBv}$ was performed $( \pm 1.5 \mathrm{~mm}$ length). They were first separated from non-living objects and then classified into nine zooplankton categories: appendicularians, chaetognaths, copepods, decapod larvæ, other crustaceans, gelatinous, pteropods, thaliaceans and other zooplankton (Fig. 2 for examples of thumbnails). Adding the small copepods automatically classified, ten zooplankton categories were defined. Percentages of total abundances concerning these categories and representative species are given in Table 1.

In addition, copepods recorded during the 1995-2003 period by the Juday-Bogorov net and analyzed exactly the same way as the present work (ZooScan followed by supervised classification, see Garcia-Comas et al., 2011), were used to test the consistency of the present time series compared to already published ones at the same location (Garcia-Comas et al., 2011). Small copepods were automatically identified with a recall rate of 0.96 and a contamination rate of 0.19 (see table 1 and figure 2 in Garcia-Comas et al., 2011). The Juday-Bogorov net $\left(0.25 \mathrm{~m}^{2}\right.$ mouth aperture, $330 \mu \mathrm{m}$ mesh 


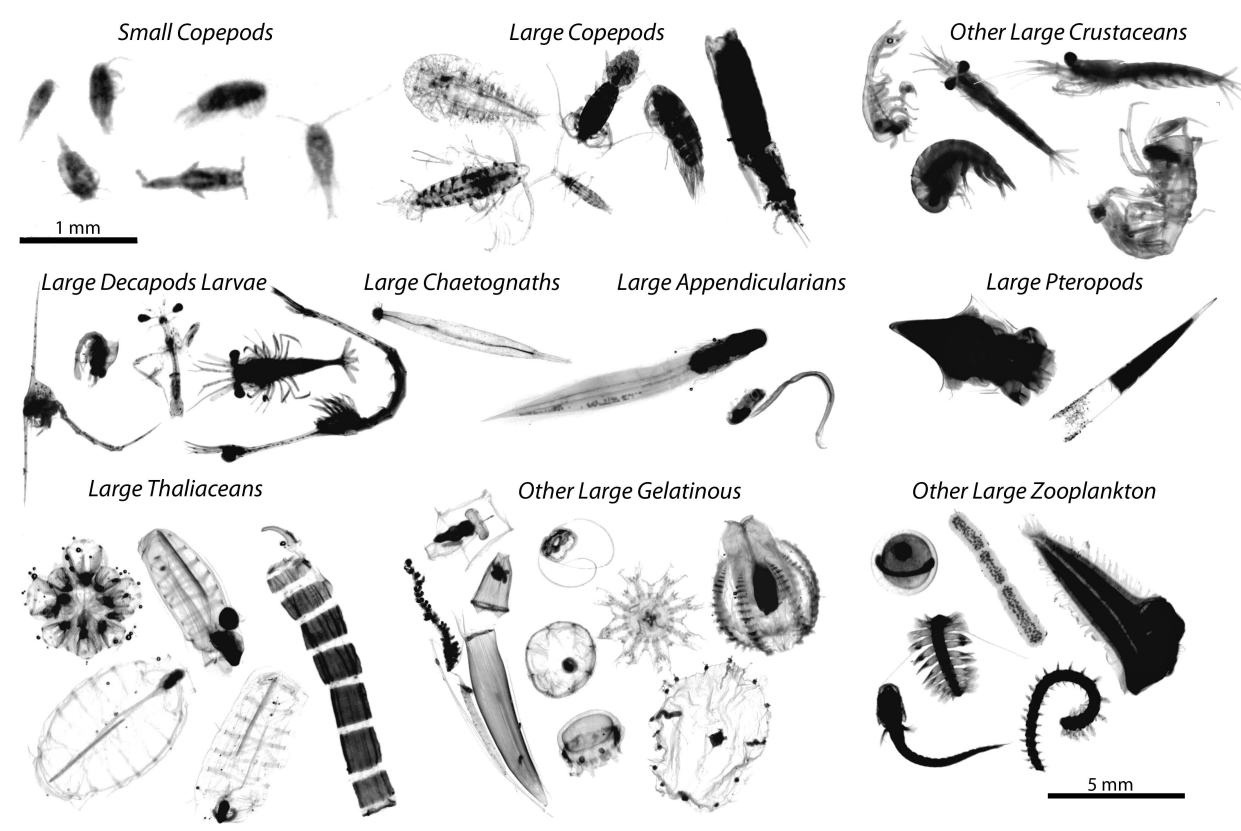

Fig. 2. Example of thumbnails directly issued from the ZooScan/ZooProcess of the ten identified zooplankton taxonomic groups. All thumbnails have the same scale (bottom right corner) except the small copepods which have their own scale on top left.

size) was used weekly from 1966 to 2003 . This allows an overlapping period of $9 \mathrm{yr}$ which (taking gaps into account) represents 201 weeks where zooplankton was sampled with both nets. Because of the differences between nets we made the comparison only on comparable sizes using Nichols and Thompson (1991) work. These authors stated that a net is quantitative when it has a mesh size of at least $75 \%$ of the width size (equivalent to minor axis) of objects it records. Considering an average minor:major axes ratio of 0.45 (average for copepods from ZooScan data, Vandromme, 2010), this represents an ellipsoidal biovolume of $0.0525 \mathrm{~mm}^{3}$ for the Juday-Bogorov. Because the mouth aperture and the towing speed of the WP2 and the Juday-Bogorov nets are similar we did not fix an upper size limit.

\subsection{Primary production and zooplankton carbon requirement}

In order to assess the role of mesozooplankton grazing on phytoplankton, we estimated the primary production (or phytoplankton carbon production) and the mesozooplankton carbon requirement. The primary production $\left(P_{\text {prod }}\right)$ was defined as in Nival et al. (1975), i.e. $P_{\text {prod }}=g_{\mathrm{p}} \cdot B_{\text {phyto }}$, where $B_{\text {phyto }}$ is the biomass of phytoplankton in $\mathrm{mgC} \mathrm{m}^{-3}$ computed as in Nival et al. (1975), i.e. $B_{\text {phyto }}=54 \cdot \mathrm{Chl}-a$. The growth of phytoplankton $\left(g_{\mathrm{p}}\right)$ is calculated using a multiplicative model which includes limitation by nitrate, irradiance and temperature (Andersen and Nival, 1988). Irradiance at depth was calculated from irradiance at the surface using the model of Raick et al. (2005) and Lacroix and Grégoire (2002).
Then the carbon requirement of zooplankton $\left(Z_{\mathrm{Creq}}\right)$, could be expressed in $\mathrm{mgC} \mathrm{m}^{-2} \mathrm{~d}^{-1}$ as (Nival et al., 1975), $Z_{\text {Creq }}=$ Ration $\cdot B_{\text {zoo }}$, where $B_{\text {zoo }}$ is the biomass of zooplankton in $\mathrm{mgC} \mathrm{m}^{-3}$, calculated using size-carbon weight relationships from Lehette and Hernández-León (2009) and Mauchline (1998) applied on samples of the WP2 (that quantitatively samples zooplankton in the size range $[0.4: 2.8] \mathrm{mm}$ ESD). The Ration is defined following Nival et al. (1975) as a function of growth rate $g_{z}$, respiration $r$ and assimilation efficiency $A$. For $r$ and $A$ we used the same values as in Nival et al. (1975), i.e. $0.19 \mathrm{~d}^{-1}$ and 0.7 , respectively. For $g_{z}$ we used the formulation of Zhou et al. (2010) which is based on Huntley and Boyd (1984) and Hirst and Bunker (2003). $g_{z}$ is a function of seawater temperature, chlorophyll- $a$ and weight of individuals $w(\mathrm{mgC}) . Z_{\text {Creq }}$ is then a function of the weight $w$. Primary production and zooplankton carbon requirement are then multiplied by $85 \mathrm{~m}$ (bottom depth at Point B) to get values in $\mathrm{mgC} \mathrm{m}^{-2} \mathrm{~d}^{-1}$.

\subsection{Analysis}

Graphs and analyzes are made using Matlab R2009b ${ }^{\circledR}$ (the Mathworks Company, inc.). First, gaps in time series (see Sect. 2.2) are filled using the robust spline smoothing toolbox for matlab of Garcia (2010). Environmental variables are averaged over the depth $(0-75 \mathrm{~m})$. Then a pre-whitening of each time series is done (see Pyper and Peterman, 1998; Rodionov, 2006) using functions "ddencmp" and "wdencmp" of the Matlab wavelet toolbox with threshold optimized to have the Durban-Watson test value of residuals as close as 
Table 1. Large zooplankton categories $\left(>0.724 \mathrm{~mm}^{3}\right)$, percentage of abundance (Ab.) of these categories among zooplankton of this size range, representative species or groups and dominant diet considered in this work. The category "Copepods (small)" comes from copepods automatically sorted from 0.032 to $0.724 \mathrm{~mm}^{3}$. The percentage corresponds to the average ratio. The large zooplankton (i.e. $>0.724 \mathrm{~mm}^{3}$ ) represents $2.0 \%$ of total zooplankton abundance.

\begin{tabular}{|c|c|c|c|}
\hline Taxonomic groups & $\% \mathrm{Ab} . / \mathrm{EBv}$ & Representative species & Dominant diet \\
\hline Copepods (small) & 72.1 & $\begin{array}{l}\text { Acartia spp., Oithona spp., Clausocalanus spp., } \\
\text { Paracalanus spp., Oncaea spp., Farranula rostrata ... }\end{array}$ & microplanktonophage/herbivors \\
\hline Appendicularians & 1.7 & Oikopleura albicans, Fritillaria pelucida ... & filter-feeders \\
\hline Chaetognaths & 15.0 & Sagitta inflata & carnivores (copepods) \\
\hline Copepods (large) & 28.0 & $\begin{array}{l}\text { Centropages spp., Temora stylifera, Calanus minor, } \\
\text { Calanus gracilis, Pleuromamma spp., Candacia spp., } \\
\text { Euchaeta marina... }\end{array}$ & omnivores \\
\hline Decapod larvæ & 4.5 & $\begin{array}{l}\text { Zoé, Protozoé and Metazoé larvæ of mostly crabs, } \\
\text { langoustine and lobsters }\end{array}$ & omnivores \\
\hline Crustaceans (other) & 6.8 & $\begin{array}{l}\text { Euphausiids (Meganyctiphanes norvegica, Nyctiphanes } \\
\text { couchii) and mysidacea }\end{array}$ & omnivores \\
\hline Gelatinous predators & 27.0 & $\begin{array}{l}\text { ctenophores (Beroe sp., Pleurobrachia sp....), } \\
\text { siphonophores (Muggia sp., Lensia sp., Agalma } \\
\text { elegans ...), Medusæ (Ephyrula of Pelagia noctiluca, } \\
\text { Rhopanolema velatum, Liriope Tetraphylla, Solmissus } \\
\text { albecans...) ... }\end{array}$ & carnivores \\
\hline Pteropods & 5.8 & Cavolinia inflexa, Creseis laciculata ... & filter-feeders/suspensivors \\
\hline Thaliaceans & 8.0 & $\begin{array}{l}\text { Thalia democratica, Salpa fusiformis, Dolioleta gegen- } \\
\text { bauri, Doliolum nationalis, Pyrosoma atlanticum ... }\end{array}$ & filter-feeders \\
\hline Zooplankton (other) & 3.2 & fish larvæ, annelids ... & mixed \\
\hline
\end{tabular}

possible from 2 , i.e. minimum autocorrelation in residuals. To detect the significant changes in zooplankton time series the STARS method was used (Rodionov, 2004, 2006).

For Principal Component Analyzes (PCA), seasonal values (standardized to zero mean and unit variance) were taken so that inter-annual fluctuations of each season for each descriptor is considered. This allows a detailed analysis of years to years variability, i.e. at which season inter-annual changes occur. We defined seasons as winter lasting from January to March, spring from April to June, summer from July to September and Autumn from October to December. This corresponds roughly to hydrological seasons as observed in records of sea water temperature at $10 \mathrm{~m}$ depth: the coldest months are February and March (median of 13.5 and $13.4^{\circ} \mathrm{C}$, respectively) and the warmest months being July, August and September (median of 22.6, 24.3 and $23.0^{\circ} \mathrm{C}$, respectively). However, transition regimes that occur within a month such as stratification and de-stratification may be not well depicted. The PCA were done separately on zooplankton and environmental datasets to assess if their main variabilities have similarities (method used in, e.g. Molinero et al., 2008; Black et al., 2010; Garcia-Comas et al., 2011). Then we added supplementary variables to PCA correlation plot (variables that have no weight in PCs extraction, e.g. Beaugrand and Ibañez, 2004). Primary production, zooplankton carbon requirement and chlorophyll- $a$ are not included in the environmental PCA which focus on climatic, physical and chemical variables. Total Zooplankton is included as supplementary variable in the zooplankton and environmental PCA, chlorophyll- $a$ and first PC of the zooplankton PCA are included as supplementary variables in the environmental PCA together with chlorophyll- $a$ at all seasons.

In addition to PCA, plots of seasonal variability showing percentiles $(\mathrm{Q} 1=25 \%, \mathrm{Q} 2=$ median, $\mathrm{Q} 3=75 \%)$ together with annual means that include the contribution of each month of some relevant parameters are presented in the Results section (Figs. 4, 5 and 6). Then, to strengthen some points of the discussion, normalized anomalies (as in GarciaComas et al., 2011) of relevant parameters are shown. Finally, Spearman rank order correlations $\left(r_{\mathrm{s}}\right)$ are calculated between parameters discussed in the text.

\section{Results}

\subsection{Consistency with previous time-series}

With the 201 weekly data from 1995 to 2005 for which the WP2 net and the Juday-Bogorov net were concomitantly used, we performed a comparison of the estimates of copepods larger than $0.0525 \mathrm{~mm}^{3}$. This lower limit ensures a comparison of copepods that are quantitatively sampled by both nets since Juday-Bogorov net undersamples 


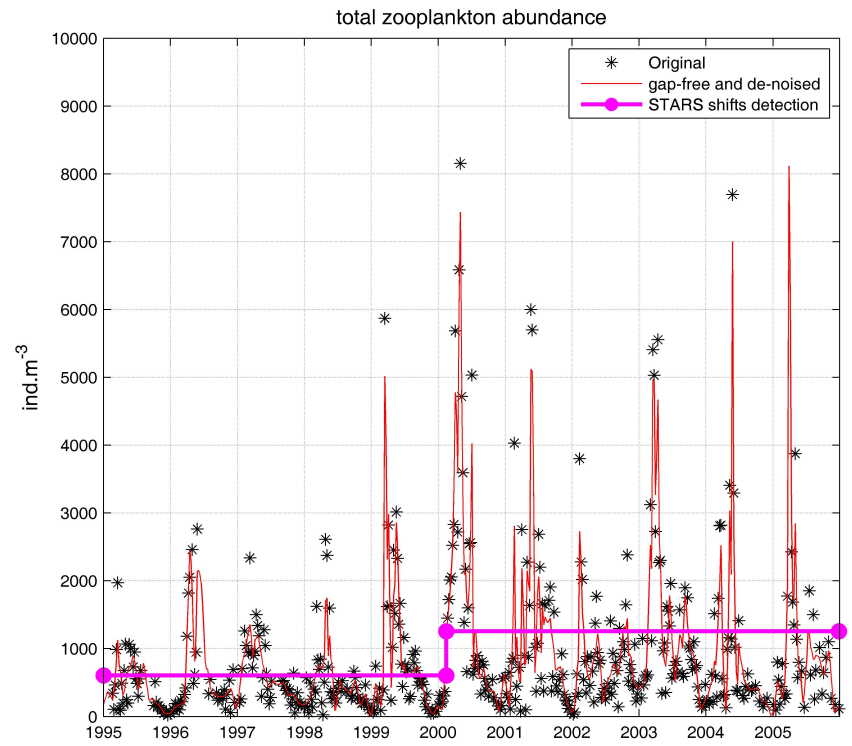

Fig. 3. Weekly time series of total zooplankton abundance. Black stars correspond to original measurements without treatment. The red curve corresponds to the time series with gaps filled using the smoothing toolbox of Garcia (2010) and pre-withened (Pyper and Peterman, 1998; Rodionov, 2006). The magenta stairs correspond to the STARS shifts detection method (Rodionov, 2004) that detects significant changes in the mean. Here a significant increase $(\alpha=0.05)$ by 1.84 is recorded in February 2000.

sizes below it (see Sect. 2.2 for details). The log of copepod abundances estimated from both nets are significantly correlated (standardized major axis regression with test of a slope, $p<0.001$, slope of 0.947 not significantly different from 1). The log of copepods biovolume is also correlated (same test, $p=0.025$, mean slope 0.958 not significantly different from 1).

Including copepods smaller than $0.0525 \mathrm{~mm}^{3}$ in the comparison would result in an underestimation of the abundance of about 3.63 times less by the Juday-Bogorov net compared to the WP2 (median value of the 201 data points, $\mathrm{Q} 1=2.37$, $\mathrm{Q} 3=6.03$ ). These results clearly show the underestimation of small copepods by the Juday-Bogorov net, but also that on comparable sizes. The results from both nets are consistent.

\subsection{Total zooplankton}

Maximum weekly values of zooplankton abundances were observed each year between February and May $(\mathrm{Q} 1=1901$, median $=4905, \mathrm{Q} 3=6546$ ind. $\left.\mathrm{m}^{-3}\right)$ and minimum weekly values were observed in December-January $(\mathrm{Q} 1=30$, median $=56, Q 3=104$ ind. $\mathrm{m}^{-3}$ ). The dates of significant changes in total zooplankton abundances weekly time series are reported in Fig. 3, using STARS method (Rodionov, 2004, 2006). We observe that the total zooplankton signifi- cantly increased from February 2000 by a factor of 1.84 on average (from 601 to 1107 ind. $\mathrm{m}^{-3}$ ).

Furthermore, differences in annual cycle between the two identified periods and inter-annual variability in zooplankton abundance are presented in Fig. 4a, b. Abundances of zooplankton are on average of 877 ind. $\mathrm{m}^{-3}$ over the whole period. The winter months (January to March) contribute to $25.8 \%$ (mean of 901 ind. $\mathrm{m}^{-3}$ ), spring months (April to June) to $42.7 \%$ (1527 ind. $\mathrm{m}^{-3}$ ), summer months to $20.7 \%$ (717 ind. $\mathrm{m}^{-3}$ ) and autumn months to $10.8 \%\left(365\right.$ ind. $\mathrm{m}^{-3}$ ) on average. A global increase occurs ca. 2000 (see Fig. 3) with years 2000, 2003, 2001 and 2005 being decreasingly the most abundant (annual means of 1517, 1287, 1202 and 1009 ind. $\mathrm{m}^{-3}$, respectively, Fig. 4b). This increase affected all seasons (Fig. 4a, b): winter months increased by 1.96 on average, spring months by 1.73 , summer months by 1.81 and autumn months by 2.13 .

\subsection{Nitrate and chlorophyll- $a$}

Nitrate and chlorophyll- $a$ seasonal and inter-annual dynamics are presented in a similar way to total zooplankton (Fig. 4a, b). Nitrate maxima occur in winter, mostly between weeks 4 to 11 (Fig. 5a), with values generally ranging from 0.5 to $2 \mu \mathrm{g}^{-1}$. The winter accounts on average for $53.9 \pm 11.3 \%$ of the annual value $(14.1 \pm 5.2,13.9 \pm 7.8$ and $18.1 \pm 8.7 \%$ for spring, summer and autumn, respectively). Years with the maximum nitrate concentrations in winter are 2003, 2002, 1999, 2005 and 2004. This pattern is sensibly different when considering annual values, notably because of large nitrate recorded in summer and autumn 2002, 2003 and 2005, which is not the case for 1999 and 2004 (see Fig. 5b). After 2000, nitrate also exhibit a clear second peak from July to October. On average nitrate increase from 2000 by 1.60 in winter, 1.75 in spring, 4.14 in summer and 1.82 in autumn.

Chlorophyll- $a$ maxima occur in winter and spring, mostly between weeks 6 to 20 (Fig. 6a), with values generally ranging from 0.35 to $0.60 \mu \mathrm{gl}^{-1}$. The winter accounts on average for $31.0 \pm 3.5 \%$ of the annual value, whereas spring accounts for $28.2 \pm 1.6 \%$, summer for $21.2 \pm 2.4 \%$ and autumn for $19.6 \pm 2.5 \%$ of the annual value. The differences between seasons are less marked than for nitrate or zooplankton (see Sect. 3.2). Years with the maximum chlorophyll$a$ concentrations are 1995 to 2000 . A decrease is observed from 2001 to 2004 with a new increase in 2005 (Fig. 6b). This decrease after 2000 is the most pronounced for spring and summer ( 0.72 and 0.73 times lower respectively; it is of 0.78 and 0.82 for winter and autumn).

\subsection{Zooplankton groups inter-annual variability}

A significant increase from 2000 was observed for the whole zooplankton (using STARS method, Fig. 3) and corresponds to the increase observed in small copepods (February 2000, see Table 2). Larger zooplankton groups increased later, 

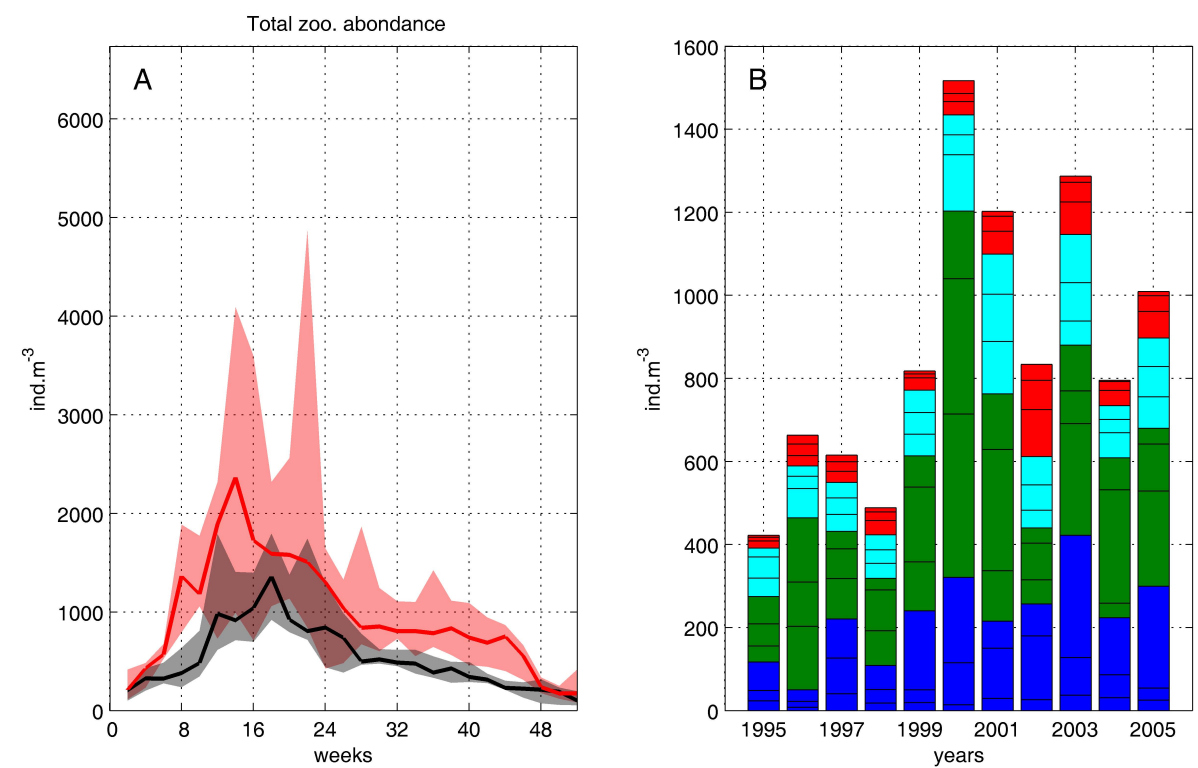

Fig. 4. (A) Median of weekly values of total zooplankton before 2000 (black) and after (red) with percentiles Q1 and Q3 (shaded area). (B) annual means with contribution of each month. blue for winter (January to March), green for spring (April to June), cyan for summer (July to September) and red for autumn (October to December).
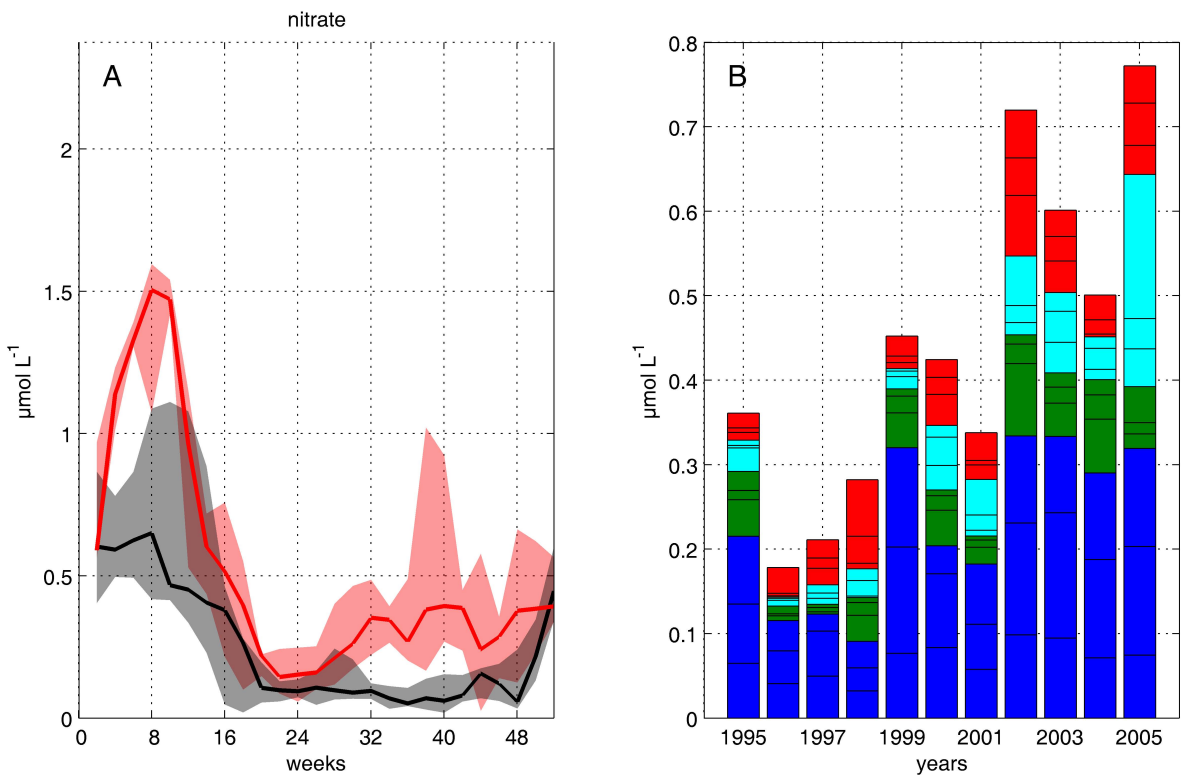

Fig. 5. (A) Median of weekly values of nitrate concentrations before 2000 (black) and after (red) with percentiles Q1 and Q3 (shaded area). (B) annual means with contribution of each month. Colors are used to easily differentiate the four seasons; blue for winter (January to March), green for spring (April to June), cyan for summer (July to September) and red for autumn (October to December).

mainly in April or March 2001 except for large copepods (see Table 2), which is significant for 7 groups out of 10 .

Main patterns of the inter-annual dynamics of zooplankton groups were extracted using PCA and are presented in Fig. 7a, b, c. Almost all taxonomic groups at all seasons are positively correlated to the PC1zoo (Fig. 7a), which represents $36 \%$ of the variance. Only thaliaceans in summer, appendicularians in summer and pteropods in spring are negatively correlated to the PC1zoo. Looking at the time trajectory (Fig. 7b), the PC1zoo strongly separates years 1995 to 1999 (low values) from years 2000 to 2005 (high values), with a maximum in 2003. The strongest correlation with PC1zoo occurred for summer values of zooplankton (orange in Fig. 7a), especially summer other crustaceans, other 

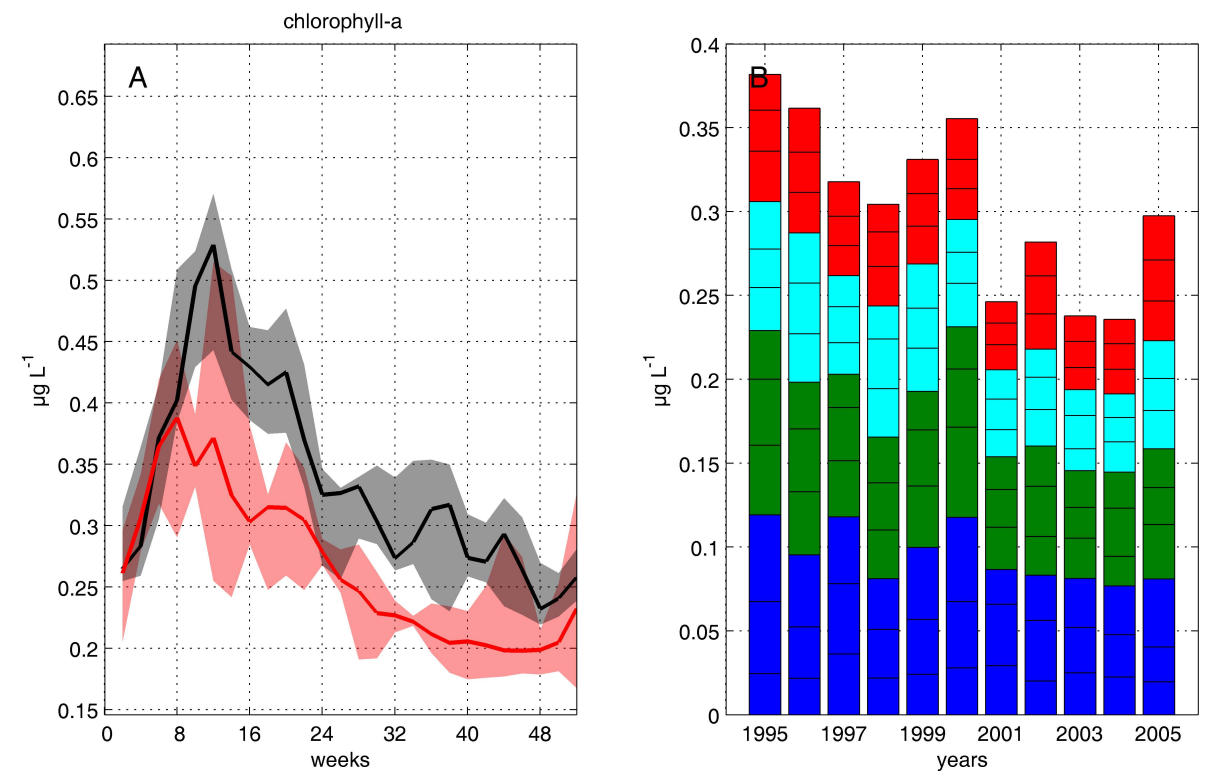

Fig. 6. (A) Median of weekly values of chlorophyll- $a$ concentrations before 2000 (black) and after (red) with percentiles Q1 and Q3 (shaded area). (B) annual means with contribution of each month. Colors are used to easily differentiate the four seasons; blue for winter (January to March), green for spring (April to June), cyan for summer (July to September) and red for autumn (October to December).

Table 2. Exact time of increase of zooplankton groups detected using STARS method (Rodionov, 2004, 2006) on weekly time series. The STARS method detects a change if the mean is significantly different between the two periods at the statistical level $\alpha=0.05$. The observed increase in appendicularians, pteropods and thaliaceans time series is not significant according to the STARS method (non significant increases are indicated in light gray). In addition, significant decreases according to the STARS method are indicated in parenthesis.

\begin{tabular}{ll}
\hline zooplankton group & STARS $(\alpha=0.05)$ \\
\hline small copepods & February 2000 \\
large copepods & September 2002 \\
decapod larvæ & April 2001 (August 2004) \\
other crustaceans & April 2001 (September 2004) \\
chaetognaths & April 2001 (November 2003) \\
appendicularians & April 2003 $(\alpha=0.2)$ \\
pteropods & July 2003 $(\alpha=0.5)$ \\
thaliaceans & June 2001 $(\alpha=0.3)$ \\
gelatinous predators & March 2001 \\
other zooplankton & March 2001 \\
\hline
\end{tabular}

zooplankton, decapod larvæ, small copepods, but also autumn other crustaceans, spring appendicularians and winter chaetognaths. The PC2zoo (19\%) shows a different pattern, mainly due to the opposition between years 2002 and 2004 (Fig. 7c) and between autumn and winter/spring of these two years. There is a clear opposition between low values that occur during the first part of 2002 (January-June) and high values that occurred at the end of the same year and year 2004 which shows an opposite trend with high values during the first part of the year and low values afterward. The main groups that contributed to the PC2zoo are autumn chaetognaths, decapod larvæ and thaliaceans, summer pteropods and winter appendicularians (positive contribution), and winter pteropods, winter other zooplankton and spring large copepods (negative correlation).

\subsection{Climatological and hydrological inter-annual variability}

PCA performed on environmental variables is presented on Fig. 8a, b, c. The PC1env (26\%) highlights years which have high values in salinities, densities and nitrate and low values in air and sea temperatures and vertical stratification especially in winter (1995, 1999, 2000, 2003, 2004 and 2005). Years with positive PC2env (14\%) have mainly high values in spring and summer irradiation, higher autumn vertical stratification, higher summer and autumn temperature, and low values in precipitations in summer leading to drier weather for this season. Total zooplankton is correlated to PC1env $\left(r_{\mathrm{s}}=0.63, p=0.044\right)$. The PC1zoo follow the same pattern but with here an insignificant correlation with PC1env $\left(r_{\mathrm{s}}=0.33\right)$. This indicates that years with high abundances of total zooplankton are partially characterized by a set of climatic and hydrological properties leading to less stratification in winter (PClenv). However, correlations are not strong enough to exclude potential major role of other physical or biological factors. Chlorophyll- $a$ is not linked to PC1env for all seasons but is negatively linked to PC2env in summer and 

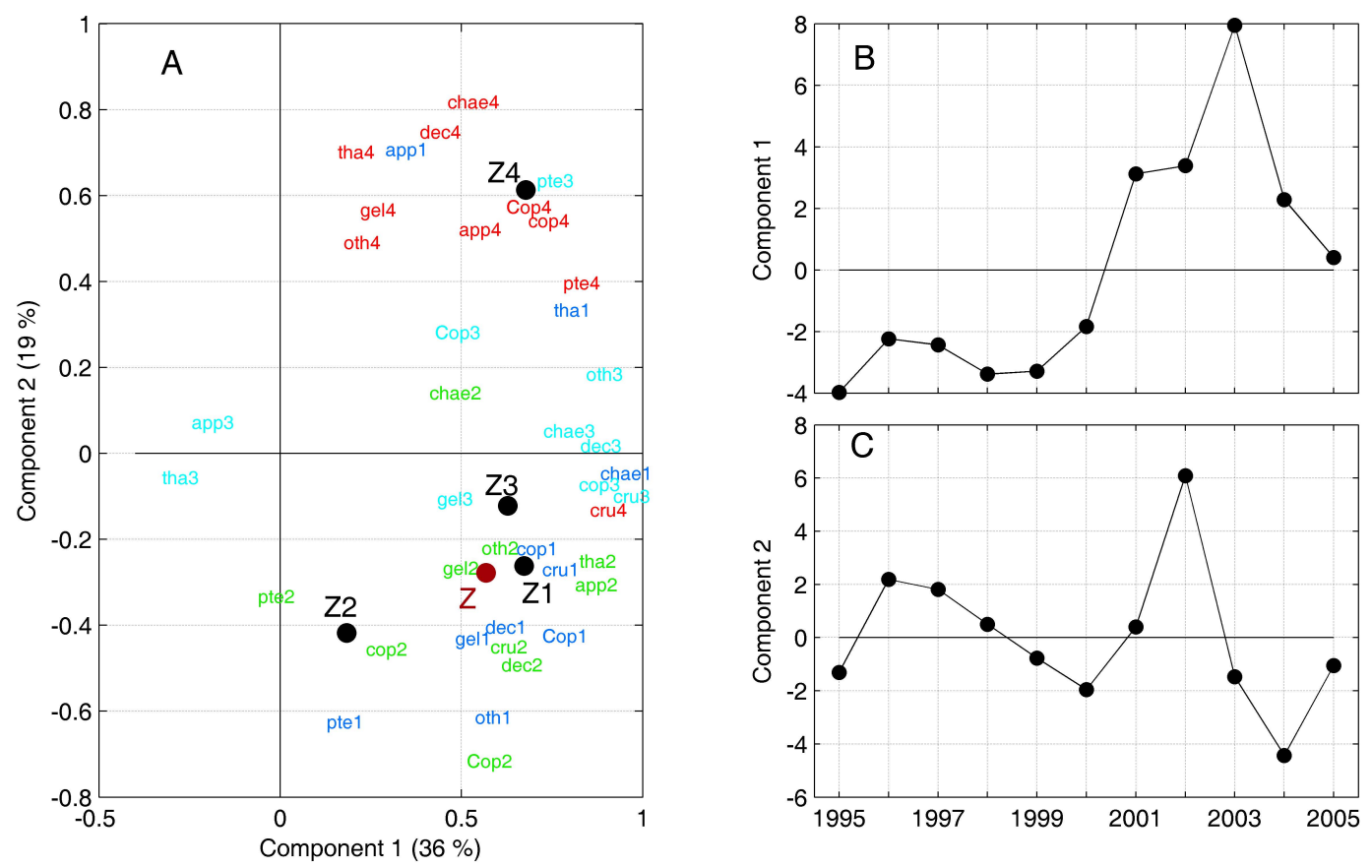

Fig. 7. Principal Component Analysis (PCA) performed on annual time series of zooplankton groups (see Table 3 for abbreviations). Season is indicated by colors and numbers. Winter (1, blue), spring (2, green), summer (3, cyan), autumn (4, red). Each annual variable is split into four seasonal variables. For example, "cop3" is the time series of annual means of small copepods in summer. The correlation plot (A) and the time trajectories $(\mathbf{B}, \mathbf{C})$ are presented for principal axes 1 and 2 . Total zooplankton $(\mathrm{Z})$ at each seasons and annually are added as supplementary variables (see Sect. 2.4).
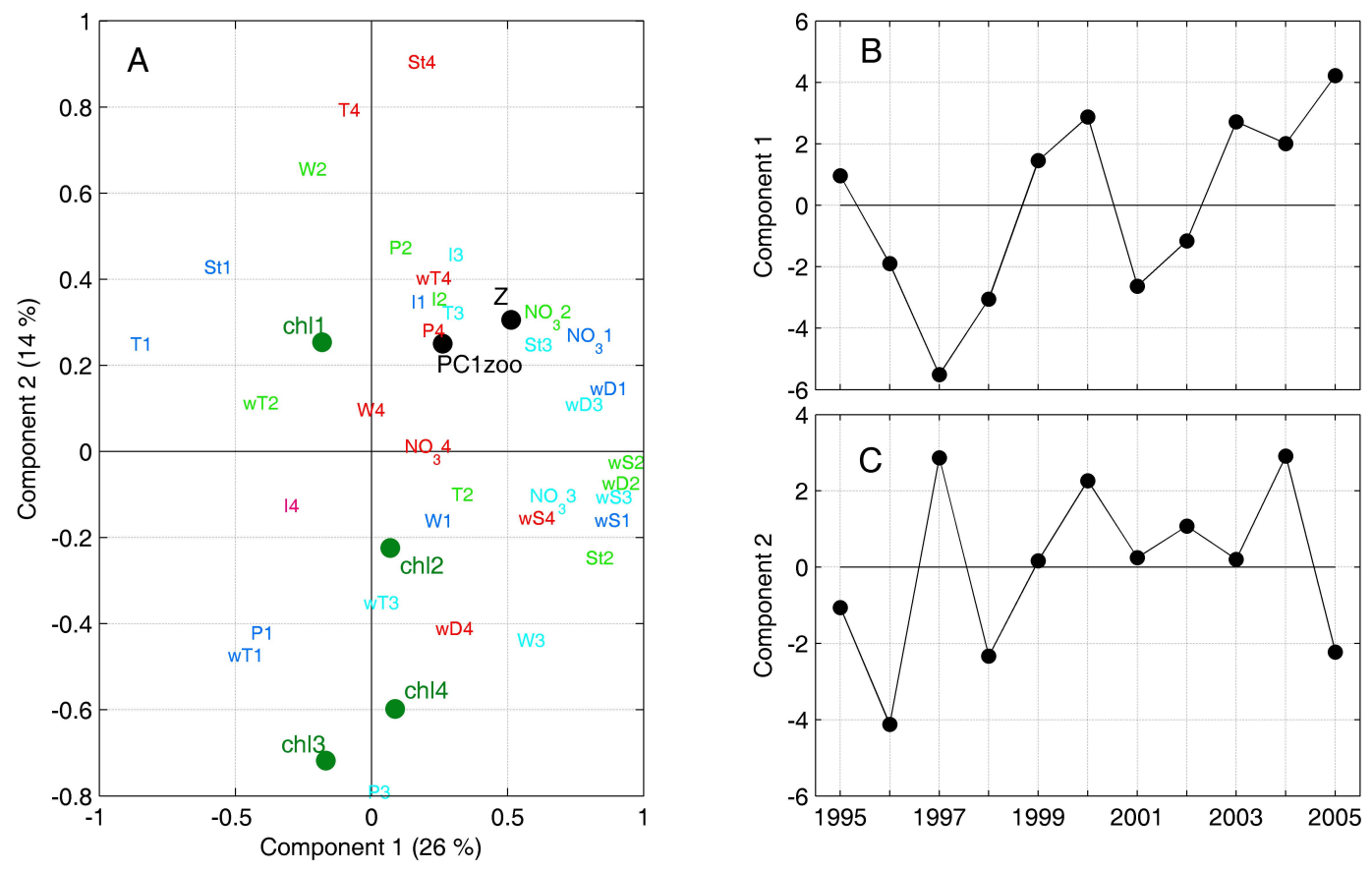

Fig. 8. As Fig. 5 for environmental variables (see Table 3 for abbreviations) with the inclusion of the total zooplankton and chlorophyll- $a$ as supplementary variables (i.e. not used to compute the PCA, see Sect. 2.4). Colors and numbers after abbreviations relate to the season as in Fig. 7. Correlation plot is presented in (A) and principal axes are presented in (B) for the PC1 and in (C) for the PC2. 
Table 3. Abbreviations used in PCA plots.

\begin{tabular}{|c|c|c|c|c|c|c|c|}
\hline $\begin{array}{l}\text { cop } \\
\text { chae } \\
\text { gel } \\
\mathrm{NO}_{3} \\
T \\
\mathrm{St} \\
-1\end{array}$ & $\begin{array}{l}\text { small copepods } \\
\text { chaetognaths } \\
\text { gelatinous predators } \\
\text { nitrate } \\
\text { air temperature } \\
\text { water stratification } \\
\text { winter }\end{array}$ & $\begin{array}{l}\text { Cop } \\
\text { app } \\
\text { oth } \\
\text { wT } \\
P \\
\text { PC1zoo } \\
\text { _2 }\end{array}$ & $\begin{array}{l}\text { large copepods } \\
\text { appendicularians } \\
\text { other zooplankton } \\
\text { water temperature } \\
\text { precipitations } \\
\text { PC1 of zooplankton } \\
\text { spring }\end{array}$ & $\begin{array}{l}\text { dec } \\
\text { pte } \\
\mathrm{Z} \\
\text { wS } \\
\text { I } \\
\text { PC2zoo } \\
\text { _3 }\end{array}$ & $\begin{array}{l}\text { decapod larvæ } \\
\text { pteropods } \\
\text { total zooplankton } \\
\text { salinity } \\
\text { irradiation } \\
\text { PC2 of zooplankton } \\
\text { summer }\end{array}$ & $\begin{array}{l}\text { cru } \\
\text { tha } \\
\text { chl } \\
\text { w } D \\
W\end{array}$ & $\begin{array}{l}\text { other crustaceans } \\
\text { thaliaceans } \\
\text { chlorophyll- } a \\
\text { density } \\
\text { wind speed }\end{array}$ \\
\hline
\end{tabular}

autumn. Winter and spring chlorophyll- $a$ values are weekly linked to PC2env. This indicates, first, that other factors than the winter climatic and hydrological properties affect the chlorophyll- $a$, and that the summer and autumn chlorophyll- $a$ are negatively affected by dry weather.

\subsection{Estimated primary production and zooplankton carbon requirement}

The estimated primary production is on average of $148 \mathrm{mgC} \mathrm{m}^{-2} \mathrm{~d}^{-1}$. The most productive year is 2002 (average of $219 \mathrm{mgC} \mathrm{m}^{-2} \mathrm{~d}^{-1}$ ), followed by $1995,2003,2005$, 2001, 2000 and 2004 (average of 187, 179, 174, 156, 149 and $143 \mathrm{mgC} \mathrm{m}^{-2} \mathrm{~d}^{-1}$, respectively). Zooplankton carbon requirement is on average of $54 \mathrm{mgC} \mathrm{m}^{-2} \mathrm{~d}^{-1}$. Years showing the highest carbon requirements are $2003\left(79 \mathrm{mgC} \mathrm{m}^{-2} \mathrm{~d}^{-1}\right)$, 2000 (72), 2004 (71), 2001 (67), 2002 (57) and 2005 $\left(55 \mathrm{mgC} \mathrm{m}^{-2} \mathrm{~d}^{-1}\right)$. Zooplankton carbon requirement represents on average $36.4 \%$ of the phytoplankton production (winter: 23.5; spring: 42.9; summer: 45.7; autumn: $43.5 \%$ ).

\section{Discussion}

\subsection{Previous analysis of the pelagic ecosystem in the NW Mediterreanean Sea}

Previous time series analysis on different components of the plankton communities at the same site highlighted the correspondence between changes in the abundance and/or composition of some target species and the shift in the local climate that occurred in the late '80s (Molinero et al., 2005, 2008). Molinero et al. $(2005,2008)$ proposed that jellyfish out-competed chaetognaths and were detrimental to copepods, which abundance dropped from the late ' $80 \mathrm{~s}$. The authors proposed a trophic reorganization due to oligotrophication related to increasing summer stratification driven by water warming in the '90s. With 10 more years to the same time series but at the community level, Garcia-Comas et al. (2011) found that total copepods and chaetognaths recovered almost the abundance of the ' 80 s by year 2003 while jellyfish remained abundant. Instead of a long term trend, the authors proposed a quasi decadal fluctuation driven by changes in winter mixing intensity acting through the input of nutrient and phytoplankton production. They suggested that dry years in the '80s and from 1999 to 2003 would lead in winter to the cooling of seawater surface temperature and to an increase of the surface salinity, hence to an increase of density close to deep values causing deep winter vertical mixing in the coastal Ligurian Sea. The authors proposed that zooplankton would benefit from higher phytoplankton biomass. However, their study lacked observations of phytoplankton biomasses and of small copepods which were not collected in the Juday-Bogorov net (mesh size of $330 \mu \mathrm{m}$ see Sect. 3.1). In addition, recent study at an open sea site in the Ligurian Sea (Dyfamed) supports the hypothesis of a stronger convection from winter 1999 to 2006 (except for years 2001 and 2002). A strong link between climate variability and notable precipitations and phytoplankton production and composition was suggested (Marty and Chiavérini, 2010). Deep convection brought to the surface high levels of nutrients that triggered an intense phytoplankton bloom composed mainly of diatoms (Marty and Chiavérini, 2010). Moreover, in the coastal zone of the Bay of Calvi (Northern Corsica, Ligurian Sea), the phytoplankton blooms were reported to decrease from 1978 to 1998 as a possible consequence of lower mixing related to a salinity decrease and a temperature increase, which was assumed to entail less nutrient replenishment (Goffart et al., 2002). The poor sampling frequency (only $5 \mathrm{yr}$ in a $20 \mathrm{yr}$ 's time series) prevented the author to determine the detailed controlling factors. But surface salinity appears to be the main determinant structuring the phytoplankton community. Other biologically-oriented studies in the NW Mediterranean sea for medusæ (Goy, 1997; Buecher et al., 1997), dolioliids (Menard et al., 1997) also report about changes between "dry" and "wet" years in the '80s. Finally, physically and modeling oriented studies also insist on recent intensification of winter convective events in the North Western Mediterranean Sea (e.g. Bethoux et al., 2002; Herrmann et al., 2010; Marty and Chiavérini, 2010).

In order to confirm zooplankton changes ca. 2000 we have analyzed an independent zooplankton time series. The aim is to further understand the prevailing mechanisms using a more comprehensive data on local climate, hydrology, nutrients and phytoplankton. Results demonstrate significant changes of different ecosystem components that occurred during years 1999/2000 depending on the target components 

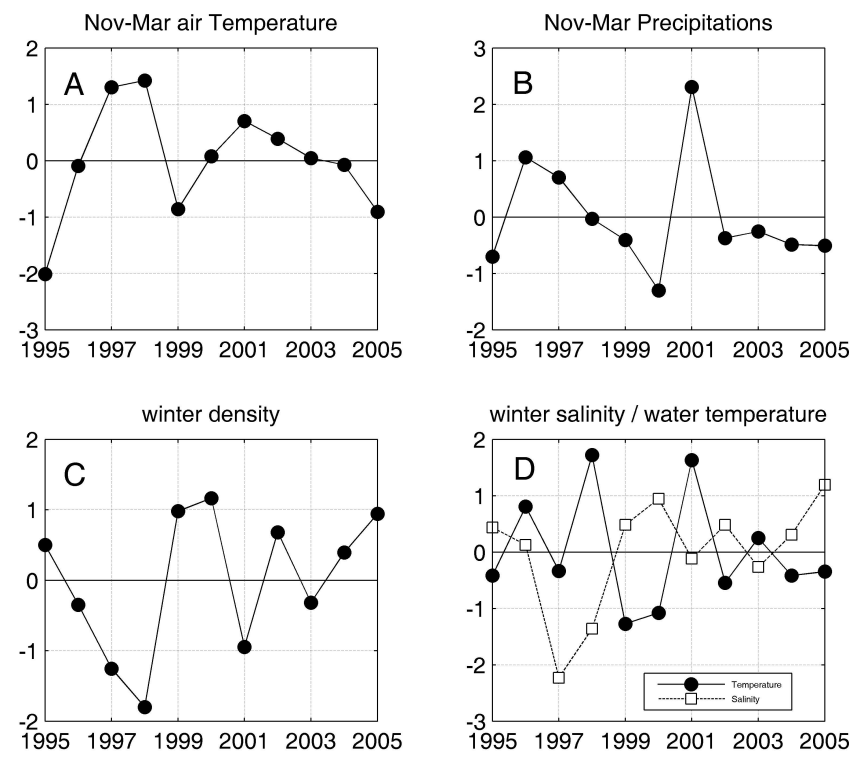

Fig. 9. Annual normalized anomalies of wet season (i.e. November to March) air temperatures (A), precipitations (B), winter density $(\mathbf{C})$ and sea salinity and temperatures (D).

(zooplankton, nutrient, hydrology). Therefore, we have averaged data from these two periods so as to investigate seasonal changes in each period. However, some years within each period may depart slightly from the mean seasonal cycle showing that inter-annual variability is present within each period. In the next sections we will evaluate the role of environmental factors that are determinant in structuring the pelagic ecosystem during the two periods.

\subsection{Winter-spring physical and climatic forcing}

In the NW Mediterranean Sea, deep convection occurs during periods of high salinity and low temperature of surface waters influenced by winter atmospheric forcing (Leaman and Schott, 1991; Bethoux et al., 1998, 2002). Climatic preconditioning in autumn (October, November and December) and early winter (January) with strong winds and low precipitations are determinant for the intensity of the mixing in late winter (March and February) (Bethoux et al., 1998, 2002). Therefore Fig. 9 presents precipitation and air temperature during the whole autumn and winter periods and the hydrological data only during winter. The pre-conditioning phase results in increased surface density and allows surface water to sink into the deep layer, mixing the water column. Recent increases of winter vertical mixing and convection strength were mainly related to an increase of salinity due to a decrease of precipitations and rivers flow in the NW Mediterranean Sea (e.g. Skliris et al., 2007; Ludwig et al., 2009; Marty and Chiavérini, 2010; Vargas-Yanez et al., 2010; Herrmann et al., 2010). The inter-annual variability of the strength of the winter vertical mixing clearly appears in the
PC1env (Fig. 8a, b). The PC1env mainly opposed years with low air/sea winter temperatures, high winter salinity, high winter density and low stratification. During these years, the frequency of surface density higher than 28.8 in winter (see Table 4) is increased. This value was observed by Stemmann et al. (2008) to be found deeper than $150 \mathrm{~m}$ in the Ligurian Sea coastal zone near Point B and observation of values larger than 28.8 indicate mixing of deeper waters to the surface, bringing with them elevated nutrient levels (Garcia-Comas et al., 2011). Therefore all proxies of winter vertical mixing demonstrate that strongest vertical mixing occurred in winters 2005, 2000, 1999, 1995, 2003 and 2004. According to the PC1env, the main climatological determinant of these strong winter vertical mixing are the cold and saline winter. Both precipitations and temperature anomalies from November to March (Fig. 9) are negatively correlated to winter densities $\left(r_{\mathrm{s}}=-82, p=0.0037\right.$ for precipitations; $r_{\mathrm{s}}=-0.78, p=0.0070$ for temperature). Both autumn/winter temperatures and precipitations need to be considered to account for the strength of the winter vertical mixing; for example, 1998 shows the lowest seawater densities (and mixing) because of highest temperatures but close to average precipitations. In contrast, year 2000 shows the highest seawater densities with close to average temperatures, but the lowest precipitations of the eleven years (Fig. 9).

The main consequence of an increase in winter vertical mixing is a tendency to a stronger replenishment of nutrients (Garcia-Comas et al., 2011), yet not supported in the present work by the direct correlation between winter surface density and winter nitrate $\left(r_{\mathrm{s}}=0.61, p=0.052\right)$. This insignificant correlation is probably due to the high levels of nitrate observed in 2003 which were associated with an average convection intensity (see Figs. 10a and 9c, without year $2003 r_{\mathrm{s}}=0.73$ and $p=0.021$ ). Marty and Chiavérini (2010) observed in the central Ligurian Sea an increase of nitrate concentration in February by about 3 times between years with low and high vertical mixing. In the present work, years 1997/1998, estimated to be the less mixed in winter (see Fig. 8b), were almost 7 times lower in nitrate concentration in February compared to year 2005. From the literature, such increases in nitrate and other nutrients at the end of the winter have been related to a significant increase in phytoplankton productivity, mainly diatoms, in the Ligurian Sea (Goffart et al., 2002; Nezlin et al., 2004; Marty and Chiavérini, 2010), and to a significant increase in zooplankton abundances at Point B (Garcia-Comas et al., 2011).

\subsection{Possible trophic control}

A striking result of our analysis is an opposite pattern in the inter-annual variability between chlorophyll- $a$ and zooplankton (Figs. 8a, 6a, b and 4a, b) with a significant correlation $\left(r_{\mathrm{s}}=-0.77, p=0.0081\right)$ between annual values of chlorophyll- $a$ and the PC1zoo. This opposition seems mainly driven by spring to autumn values of chlorophyll- $a$ (see 
Table 4. Frequency of density $\geq 28.8$ during winter months (January to March) in the surface layer (0-10 m).

\begin{tabular}{cccccccccccc}
\hline year & 1995 & 1996 & 1997 & 1998 & 1999 & 2000 & 2001 & 2002 & 2003 & 2004 & 2005 \\
\hline freq. & 0.091 & 0 & 0 & 0 & 0.454 & 0.615 & 0 & 0 & 0.250 & 0.167 & 0.583 \\
\hline
\end{tabular}
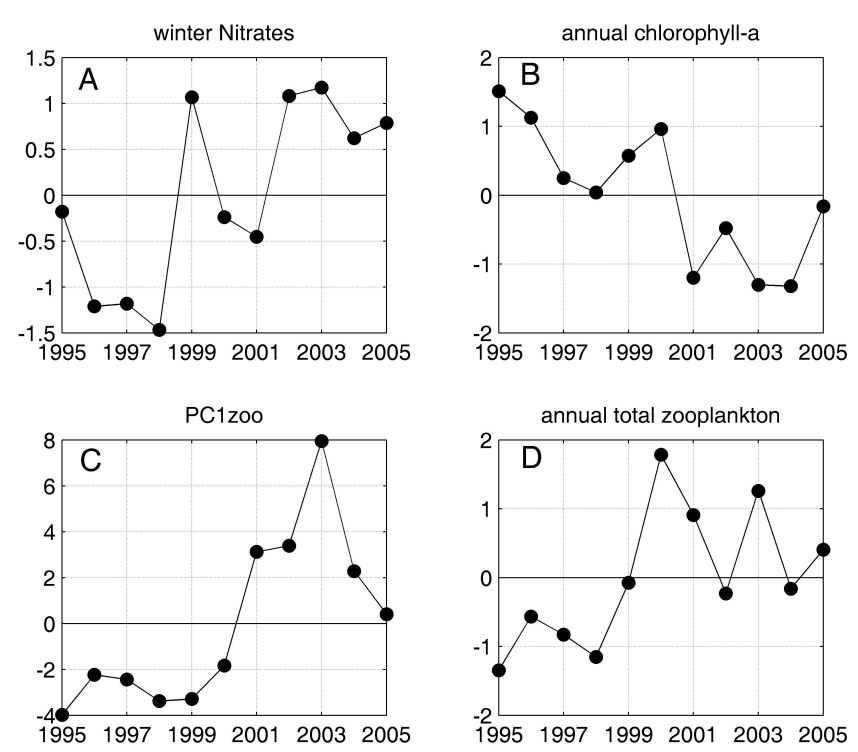

Fig. 10. Annual normalized anomalies of (A) winter nitrate, (B) annual chlorophyll- $a$ (Figs. 8a, 5b and 6b), (C) PC1zoo (Fig. 7a, b) and (D) annual total zooplankton (Figs. 7a and 4).

PC2env on Fig. 8a). Nitrate concentrations show a similar tendency as the total zooplankton and a pattern that is opposite to that of chlorophyll- $a$ on the inter-annual time scale (Fig. 5b) with larger values after 2000 at all seasons (Fig. 5a). The global pattern of these interactions on the inter-annual time scale is simply shown on Fig. 10. It clearly appears that nitrate and total zooplankton anomalies signs opposed to chlorophyll- $a$ ones (except for years 1999 and 2001).

This temporal dynamic stands at odds with the common conceptual model that favorable nutrient conditions result in high phytoplankton concentration. The opposite inter-annual variability of chlorophyll- $a$ as compared to zooplankton and nitrate concentrations strongly suggests that grazers control primary producers as it was suggested in other oceanic studies ("top-down" control, Micheli et al., 1999; Shurin et al., 2002; Graneli and Turner, 2002; Feuchtmayr et al., 2004; Borer et al., 2005; Sommer and Sommer, 2006; Sommer, 2008; Wiltshire et al., 2008; Landry et al., 2009; Fuchs and Franks, 2010). Previous analyzes at the same location focused on zooplankton, thus chlorophyll- $a$ dynamics were not observed and this control was not discussed (Molinero et al., 2005, 2008; Conversi et al., 2010; Garcia-Comas et al., 2011). Moreover, studies focusing on phytoplankton in the central and coastal Ligurian sea did not sample zooplankton
(Marty and Chiavérini, 2010; Goffart et al., 2002). However, the two latter studies showed that nutrients and chlorophyll- $a$ were positively correlated. This is potentially due to lower zooplankton biomasses in those locations as compared to the present site $-15-30 \mathrm{mgDW} \mathrm{m}^{-3}$ in Dyfamed, (Gasparini et al., 2004); 45-105 $\mathrm{mgDW} \mathrm{m}^{-3}$ in Calvi, Corsica, (Hecq et al., 1981; Brohée et al., 1989; Skliris et al., 2001); to be compared to $20-700 \mathrm{mgDW} \mathrm{m}^{-3}$ at Point B (using conversion factors in Lehette and Hernández-León, 2009). The possibility of a "top-down" control in our study is unfortunately not supported by experimental evidences. However, estimates of primary production and zooplankton carbon requirements (Sects. 2.3 and 3.6), show a mean ratio of $\approx 40 \%$. This ratio corresponds to values estimated by Gaudy et al. (2003) in the Gulf of Lion (NW Mediterranean). These authors mentioned that zooplankton could consume from 9 to $69 \%$ in spring and from 6 to $83 \%$ in winter of the primary production (which ranged from 54 to $19 \mathrm{mgC} \mathrm{m}^{-2} \mathrm{~d}^{-1}$ ). Top down control is also supported by the observation that the start of the phytoplankton bloom is independent of the period, but that differences between them occur after week 8 (Fig. 6a) at a time when zooplankton concentration is increased by a factor of three between the two periods (Fig. 4a). Later in the year, zooplankton concentrations remain high (as observed in the '80s during dry years by Garcia-Comas et al., 2011), probably controlling phytoplankton until October. The summer-autumn grazing may be sufficient to control phytoplankton production in spite of higher loads of nitrate those same years (especially in 2003 and 2005).

Therefore, zooplankton top down control of phytoplankton cannot be demonstrated; but observed opposite annual temporal patterns, compared annual cycles and calculated high zooplankton carbon demand strongly suggest that this control may occur every year from March to late October.

Interestingly, the decrease of chlorophyll- $a$ started in 2001 with the increase of other large zooplankton groups (PC1zoo) (i.e. 2001-2003, see Table 2) while the increase of nitrate and total zooplankton started in 1999-2000 (see Table 2 and Fig. 10). In addition, chlorophyll- $a$ increases in 2005, concomitantly with a decrease of the PC1zoo (Fig. 7b). According to previous empirical and theoretical works, such control occurs mainly when a sustained co-existence between zooplankton feeding on different parts of the phytoplankton size spectrum is observed (Micheli et al., 1999; Shurin et al., 2002; Feuchtmayr et al., 2004; Borer et al., 2005; Sommer and Sommer, 2006; Sommer, 2008; Fuchs and Franks, 2010). This can be the case in oceans where, 
for example, a long-term coexistence of tunicates and copepods is observed, or in lakes with a co-existence of copepods and Daphnia (Sommer, 2008). Copepods alone will feed only on large phytoplankton (thus decreasing the competitive pressure on small phytoplankton), or will feed on microzooplankton (thus decreasing the grazing pressure on small phytoplankton), both cases are likely to increase biomass of small phytoplankton - while filter-feeders (thaliaceans, appendicularians and also pteropods here) will feed on all phytoplankton sizes (Sommer, 2008). The predominance of filter-feeders from 2001 to 2004 may be responsible for low values of chlorophyll- $a$ observed over these years at all seasons. Yet, microzooplankton are important grazers of small phytoplankton (e.g. Calbet and Landry, 1999, 2004) and food for mesozooplankton. Further measurements will be needed to fully understand trophic links at this location.

\subsection{Other biotic and abiotic effects}

The winter forcing caused by nutrient replenishment due to intense mixing seems to explain a large part of the inter-annual variability of the zooplankton community (see Sects. 4.2 and 4.3). However several years stand at odds with this conceptual schematic (e.g. 1995, 1999, 2001 and 2002) by showing an opposite pattern between the strength of the winter mixing and the total zooplankton reached during the year. Molinero et al. $(2005,2008)$ proposed that the inter-annual fluctuations of the zooplankton communities were mainly determined by the summer climate (negative link with summer irradiation, see Sect. 4.1). Here, significant and positive correlations are observed between zooplankton and cumulated spring/summer (April-September) irradiation $\left(r_{\mathrm{s}}=0.65, p=0.034\right.$, with total annual values of zooplankton and $r_{\mathrm{s}}=0.74, p=0.013$, with the PC1zoo). This increase of solar irradiation was associated to an increase in stratification (see PCA, Fig. 8a). Such a positive effect of stratification was also observed by Aksnes and Ohman (2009) and Rykaczewski and Dunne (2010) in the California Current Ecosystem who have suggested a possible "optimum", highlighting the non-linear response to stratification. In the present case it is difficult to disentangle possible beneficial effects from increased stratification (with years after ca. 2000 being closer to the "optimum") from the winter forcing that could propagate through the year. However, spring/summer climate may play a role in the inter-annual variability of the system, yet in a different way as expected by previous studies. Thus, longer time series will be needed to get various patterns of winter and spring/summer forcing.

Another inter-annual variation was observed in the timelag between the appearances of the different taxonomic groups (see Table 2). It appears that most of the large groups increased from 2001 to 2003 whereas small copepods increased from 2000. Such a time-lag was already observed at the same location by Garcia-Comas et al. (2011) in the $1981 / 1983$ and 1999/2000 transitions. The reason for the time lag is not understood but seems to be a constant feature in the studied area. A possible explanation lies in the time needed by large zooplankton to recover from the extremely low abundances reached during unfavorable periods (especially in oligotrophic waters of the Mediterranean Sea). Such a time lag in the responses of the different groups can explain the year 2000 peculiarity in which the herbivorous community was mainly composed of copepods and not of filterfeeders, reducing the "top-down" control on phytoplankton from zooplankton previously mentioned (see above).

Finally, the second peak of nitrate observed after year 2000 from August to November is related to stronger wind, saltier, more dense waters and more stratification (see W3, wS3-4, wD3 and st3 in Fig. 8a). The higher stratification in such wind conditions is explained by the averaging over three months that dampen the short term de-stratification (data not shown). Altogether the late summer/autumn patterns suggest that vertical mixing upwelled nitrate to the surface more efficiently in the second period (2000-2005). The increased of nitrate did not trigger phytoplankton accumulation but may have contributed to maintain high levels of zooplankton biomass in this period. These results suggest also that the autumn bloom may be also controlled by zooplankton. Although important, this second high productive period represents only a small proportion of total zooplankton interannual changes (August to November months represent on average $21.4 \%$ of the annual zooplankton abundances, Sect. 3.2 and Fig. 4b).

\section{Conclusions}

Using a new $11 \mathrm{yr}$ 's multiparametric time series including zooplankton collected with a WP2 net, we show that:

- Zooplankton abundances increased almost by two from 2000 to 2005 compared to $1995-1999$ but that strong inter-annual variability is observed in both periods.

- An important driving factor of these fluctuations is the strength of the winter mixing determined by winter precipitations and air temperature. Summer/autumn variability in mixing contributes to a smaller extend to the observed changes.

- A clear opposite evolution of nitrate and zooplankton vs. chlorophyll- $a$ suggesting a strong "top-down" control of phytoplankton spring and autumn blooms by zooplankton.

This study confirms that the pelagic ecosystem in the Ligurian Sea has not shifted toward a long-term oligotrophic state as a consequence of communities reorganization in a warming environment (Molinero et al., 2008; Conversi et al., 2010). Instead, this study, together with other studies (Garcia-Comas et al., 2011; Marty and Chiavérini, 2010), 
suggest that the plankton community responds to interannual climatic changes related to the oscillation of dry and wet periods in the NW Mediterranean Sea. The $40 \mathrm{yr}$ zooplankton time series at Point B (this work and Garcia-Comas et al., 2011) is not long enough to disentangle the impact of inter-annual changes in the precipitation regime from the impact of the long term warming of the Mediterranean Sea (Vargas-Yanez et al., 2010). In addition, current data available on the interactions between phytoplankton and zooplankton is not sufficient to understand fully the complex functioning of the plankton ecosystem. Therefore future studies should complement the current observations by measurements of rates (primary and secondary production) and estimates of heterotrophic protozoa abundances, phytoplankton size spectra or main taxonomic groups.

Acknowledgements. This study was supported by the SESAME IP of the European Commission's Sixth Framework Programme, under the priority Sustainable Development, Global Change and Ecosystems, Contract No. GOCE-2006-036949. We would like to thank the anonymous reviewers who greatly helped to improve the quality of the manuscript. We thank also Jack Costello for spell checking us. We gratefully thank colleagues who participate in gathering data, especially in scanning zooplankton samples, and for their general help: Corinne Desnos, Caroline Warembourg, Isabelle Palazzoli and Marc Picheral. We also thank the offices RADE-ZOO and SOMLIT -SORADE at the "Observatoire Océanographique de Villefranche-sur-mer (OOV)" for providing hydrobiological data, and the teams headed by Jean-Yves Carval and Jean-Luc Prévost, of the NO Sagitta II and NO Velelle, for their field work. We finally thank "Météo France" for providing the meteorological data. Pieter Vandromme was financially supported by the "Ministère de l'Éducation et de la Recherche" and by the CNRS (France).

Edited by: G. Herndl

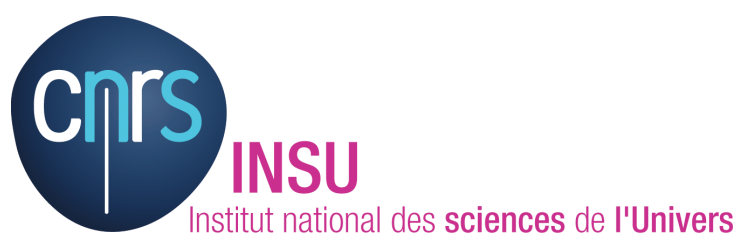

The publication of this article is financed by CNRS-INSU.

\section{References}

Aksnes, D. L. and Ohman, M. D.: Multi-Decadal Shoaling of the Euphotic Zone in the Southern Sector of the California Current System, Limnol. Oceanogr., 54, 1272-1281, 2009.

Alheit, J. and Bakun, A.: Population Synchronies Within and Between Ocean Basins: Apparent Teleconnections and Implications as to Physical-Biological Linkage Mechanisms, J. Marine Syst., 79, 267-285, 2010.

Aminot, A. and Kérouel, R.: Dissolved Organic Carbon, Nitrogen and Phosphorus in the N-E Atlantic and the N-W Mediterranean With Particular Reference to Non-Refractory Fractions and Degradation, Deep-Sea Res. Pt. I, 51, 1975-1999, 2004.
Andersen, V. and Nival, P.: A Pelagic Ecosystem Model Simulating Production and Sedimentation of Biogenic Particles - Role of Salps and Copepods, Mar. Ecol.-Prog. Ser., 44, 37-50, 1988.

Beaugrand, G.: The North Sea Regime Shift: Evidence, Causes, Mechanisms and Consequences, Prog. Oceanogr., 60, 245-262, 2004.

Beaugrand, G. and Ibañez, F.: Monitoring Marine Plankton Ecosystems. II: Long-Term Changes in North Sea Calanoid Copepods in Relation to Hydro-Climatic Variability, Mar. Ecol.-Prog. Ser., 284, 35-47, 2004.

Berline, L., Siokou-Frangou, I., Marasović, I., Vidjak, O., Fernàndes De Puelles, M. L., Mazzocchi, M. G., Assimakopoulou, G., Zervoudaki, S., Fonda Umani, S., Conversi, A., Garcia-Comas, C., Ibañez, F., Gasparini, S., Stemmann, L., and Gorsky, G.: Intercomparison of Six Mediterranean Zooplankton Time Series, Prog. Oceanogr., accepted, 2011.

Bethoux, J. P., Gentili, B., and Tailliez, D.: Warming and Freshwater Budget Change in the Mediterranean Since the 1940s, Their Possible Relation to the Greenhouse Effect, Geophys. Res. Lett., 25, 1023-1026, 1998.

Bethoux, J. P., De Madron, X. D., Nyffeler, F., and Tailliez, D.: Deep Water in the Western Mediterranean: Peculiar 1999 and 2000 Characteristics, Shelf Formation Hypothesis, Variability Since 1970 and Geochemical Inferences, J. Marine Syst., 33, 117-131, 2002.

Black, B. A., Schroeder, I. D., Sydeman, W. J., Bograd, S. J., and Lawson, P. W.: Wintertime Ocean Conditions Synchronize Rockfish Growth and Seabird Reproduction in the Central California Current Ecosystem, Can. J. Fish. Aquat. Sci., 67, 11491158, 2010.

Borer, E. T., Seabloom, E. W., Shurin, J. B., Anderson, K. E., Blanchette, C. A., Broitman, B., Cooper, S. D., and Halpern, B. S.: What Determines the Strength of a Trophic Cascade?, Ecology, 86, 528-537, 2005.

Brohée, M., Goffart, A., Frankignoul, C., Henri, V., Mouchet, A., and Hecq, J. H.: Variations Printanières des Communautés Planctoniques en Baie de Calvi (Corse) en Relation avec les Contraintes Physiques Locales, Cah. Biol. Mar., 30, 321-328, 1989.

Buecher, E., Goy, J., Planque, B., Etienne, M., and Dallot, S.: LongTerm Fluctuations of Liriope Tetraphylla in Villefranche Bay Between 1966 and 1993 Compared to Pelagia Noctiluca Populations, Oceanol. Acta, 20, 145-157, 1997.

Calbet, A. and Landry, M. R.: Mesozooplankton Influences on the Microbial Food Web: Direct and Indirect Trophic Interactions in the Oligotrophic Open Ocean, Limnol. Oceanogr., 44, 1370 1380, 1999.

Calbet, A. and Landry, M. R.: Phytoplankton Growth, Microzooplankton Grazing, and Carbon Cycling in Marine Systems, Limnol. Oceanogr., 49, 51-57, 2004.

Calbet, A., Garrido, S., Saiz, E., Alcaraz, M., and Duarte, C. M.: Annual Zooplankton Succession in Coastal NW Mediterranean Waters: the Importance of the Smaller Size Fractions, J. Plankton Res., 23, 319-331, 2001.

Conversi, A., Fonda Umani, S., Peluso, T., Molinero, J. C., Santojanni, A., and Edwards, M.: The Mediterranean Sea Regime Shift at the End of the 1980s, and Intriguing Parallelisms with other European Basins, Plos One, 5, e10633, doi:10.1371/journal.pone.0010633, 2010.

Feuchtmayr, H., Zollner, E., Santer, B., Sommer, U., and Grey, J.: 
Zooplankton Interactions in an Enclosure Experiment: Insights from Stable Isotope Analyses, Freshwater Biol., 49, 1495-1504, 2004.

Fuchs, H. L. and Franks, P. J. S.: Plankton Community Properties Determined By Nutrients and Size-Selective Feeding, Mar. Ecol.-Prog. Ser., 413, 1-15, 2010.

Gallienne, C. P. and Robins, D. B.: Is Oithona the most Important Copepod in the World's Oceans?, J. Plankton Res., 23, 14211432, 2001.

Garcia, D.: Robust Smoothing of Gridded Data in One and Higher Dimensions with Missing Values, Comput. Stat. Data An., 54, 1167-1178, 2010.

Garcia-Comas, C., Stemmann, L., Ibanez, F., Berline, L., Mazzocchi, M. G., Gasparini, S., Picheral, M., and Gorsky, G.: Zooplankton Long-Term Changes in the Nw Mediterranean Sea: Decadal Periodicity Forced By Winter Hydrographic Conditions Related to Large-Scale Atmospheric Changes?, J. Marine Syst., 87, 216-226, 2011.

Gasparini, S.: Plankton Identifier: a Software for Automatic Recognition of Planktonic Organisms, User Manual, available at: http: //www.obs-vlfr.fr/ $\sim$ gaspari/Plankton_Identifier, 2007.

Gasparini, S., Mousseau, L., and Marty, J. C.: Zooplankton Biomass at Dyfamed Time Series Station., Pangaea, available at: http://doi.pangaea.de/10.1594/PANGAEA.183618, 2004.

Gaudy, R., Youssara, F., Diaz, F., and Raimbault, P.: Biomass, Metabolism and Nutrition of Zooplankton in the Gulf of Lions (NW Mediterranean), Oceanol. Ac., 26, 357-372, 2003.

Goberville, E., Beaugrand, G., Sautour, B., Tréguer, P., and SomlitTeam: Climate-Driven Changes in Coastal Marine Systems of Western Europe, Mar. Ecol.-Prog. Ser., 408, 129-148, 2010.

Goffart, A., Hecq, J. H., and Legendre, L.: Changes in the Development of the Winter-Spring Phytoplankton Bloom in the Bay of Calvi (NW Mediterranean) Over the Last Two Decades: a Response to Changing Climate?, Mar. Ecol.-Prog. Ser., 236, 45-60, 2002.

Gorsky, G., Ohman, M. D., Picheral, M., Gasparini, S., Stemmann, L., Romagnan, J.-B., Cawood, A., Pesant, S., Garcia-Comas, C., and Prejger, F.: Digital Zooplankton Image Analysis Using the Zooscan Integrated System, J. Plankton Res., 32, 285-303, 2010.

Goy, J.: The Medusae (cnidaria, Hydrozoa) and Their Trophic Environment: an Example in the North-Western Mediterranean, Annales De L'Institut Océanographique, 73, 159-171, 1997.

Graneli, E. and Turner, J. T.: Top-Down Regulation in CtenophoreCopepod-Ciliate-Diatom-Phytoflagellate Communities in Coastal Waters: a Mesocosm Study, Mar. Ecol.-Prog. Ser., 239, 57-68, 2002.

Hays, G. C., Richardson, A. J., and Robinson, C.: Climate Change and Marine Plankton, Trends Ecol. Evol., 20, 337-344, 2005.

Hecq, J. H., Gaspar, A., and Dauby, P.: Caractéristiques Écologiques et Biochimiques de L'Écosystème Planctonique en Baie de Calvi (Corse), Bulletin De La Société Royale Scientifique De Liège 50e Année (11-12), 440-445, 1981.

Herrmann, M., Sevault, F., Beuvier, J., and Somot, S.: What Induced the Exceptional 2005 Convection Event in the Northwestern Mediterranean Basin? Answers From a Modeling Study, J. Geophys. Res.-Oceans, 115, C12051, doi:10.1029/2010JC006162, 2010.

Hirst, A. G. and Bunker, A. J.: Growth of Marine Planktonic Copepods: Global Rates and Patterns in Relation to Chlorophyll A,
Temperature, and Body Weight, Limnol. Oceanogr., 48, 19882010, 2003.

Huntley, M. and Boyd, C.: Food-Limited Growth of Marine Zooplankton, Am. Nat., 124, 455-478, 1984.

Lacroix, G. and Grégoire, A.: Revisited Ecosystem Model (MODECOGEL) of the Ligurian Sea: Seasonal and Interannual Variability Due to Atmospheric Forcing, J. Marine Syst., 37, 229258, 2002.

Landry, M. R., Ohman, M. D., Goericke, R., Stukel, M. R., and Tsyrklevich, K.: Lagrangian Studies of Phytoplankton Growth and Grazing Relationships in a Coastal Upwelling Ecosystem Off Southern California, Prog. Oceanogr., 83, 208-216, 2009.

Leaman, K. D. and Schott, F. A.: Hydrographic Structure of the Convection Regime in the Gulf of Lions - Winter 1987, J. Phys. Oceanogr., 21, 575-598, 1991.

Lehette, P. and Hernández-León, S.: Zooplankton Biomass Estimation from Digitized Images: a Comparison Between Subtropical and Antarctic Organisms, Limnol. Oceanogr.-Meth., 7, 304-308, 2009.

Ludwig, W., Dumont, E., Meybeck, M., and Heussner, S.: River Discharges of Water and Nutrients to the Mediterranean and Black Sea: Major Drivers for Ecosystem Changes During Past and Future Decades?, Prog. Oceanogr., 80, 199-217, 2009.

Mackas, D. L. and Beaugrand, G.: Comparisons of Zooplankton Time Series, J. Marine Syst., 79, 286-304, 2010.

Marty, J. C. and Chiavérini, J.: Hydrological changes in the Ligurian Sea (NW Mediterranean, DYFAMED site) during 19952007 and biogeochemical consequences, Biogeosciences, 7, 2117-2128, doi:10.5194/bg-7-2117-2010, 2010.

Mauchline, J.: The Biology of Calanoid Copepods, Adv. Mar. Biol., 33, 710 pp., 1998.

Mazzocchi, M. G., Christou, E. D., Di Capua, I., De Puelles, M. L. F., Fonda-Umani, S., Molinero, J. C., Nival, P., and SiokouFrangou, I.: Temporal Variability of Centropages Typicus in the Mediterranean Sea Over Seasonal-To-Decadal Scales, Prog. Oceanogr., 72, 214-232, 2007.

Menard, F., Fromentin, J. M., Goy, J., and Dallot, S.: Temporal Fluctuations of Doliolid Abundance in the Bay of VillefrancheSur-Mer (northwestern Mediterranean Sea) From 1967 to 1990, Oceanol. Acta, 20, 733-742, 1997.

Micheli, F., Cottingham, K. L., Bascompte, J., Bjornstad, O. N., Eckert, G. L., Fischer, J. M., Keitt, T. H., Kendall, B. E., Klug, J. L., and Rusak, J. A.: The Dual Nature of Community Variability, Oikos, 85, 161-169, 1999.

Molinero, J. C., Ibañez, F., Nival, P., Buecher, E., and Souissi, S.: North Atlantic Climate and Northwestern Mediterranean Plankton Variability, Limnol. Oceanogr., 50, 1213-1220, 2005.

Molinero, J. C., Ibañez, F., Souissi, S., Buecher, E., Dallot, S., and Nival, P.: Climate Control on the Long-Term Anomalous Changes of Zooplankton Communities in the Northwestern Mediterranean, Global Change Biol., 14, 11-26, 2008.

Nezlin, N. P., Lacroix, G., Kostianoy, A. G., and Djenidi, S.: Remotely Sensed Seasonal Dynamics of Phytoplankton in the Ligurian Sea in 1997-1999, J. Geophys. Res.-Oceans, 109, C07013, doi:10.1029/2000JC000628, 2004.

Nichols, J. H. and Thompson, A. B.: Mesh Selection of Copepodite and Nauplius Stages of 4 Calanoid Copepod Species, J. Plankton Res., 13, 661-671, 1991.

Nival, P., Nival, S., and Thiriot, A.: Influence ds Conditions 
Hivernales sur les Productions Phyto- et Zooplanctoniques en Méditerranée Nord-Occidentale, Mar. Biol., 31, 249-270, 1975.

Österblom, H., Hansson, S., Larsson, U., Hjerne, O., Wulff, F., Elmgren, R., and Folke, C.: Human-Induced Trophic Cascades and Ecological Regime Shifts in the Baltic Sea, Ecosystems, 10, 877889, 2007.

Perry, R. I., Batchelder, H. P., Mackas, D. L., Chiba, S., Durbin, E., Greve, W., and Verheye, H. M.: Identifying Global Synchronies in Marine Zooplankton Populations: Issues and Opportunities, Ices J. Mar. Sci., 61, 445-456, 2004.

Pyper, B. J. and Peterman, R. M.: Comparison of Methods to Account for Autocorrelation in Correlation Analyses of Fish Data, Can. J. Fish. Aquat. Sci., 55, 2710-2710, 1998.

Raick, C., Delhez, E. J. M., Soetaert, K., and Gregoire, M.: Study of the Seasonal Cycle of the Biogeochemical Processes in the Ligurian Sea Using a 1D Interdisciplinary Model, J. Marine Syst., 55, 177-203, 2005.

Rakotomalala, R.: Tanagra: une Plate-Forme D'Expérimentation pour la Fouille de Données, Modulad, 32, 71-85, 2005.

Reid, P. C., Borges, M. D., and Svendsen, E.: A Regime Shift in the North Sea Circa 1988 Linked to Changes in the North Sea Horse Mackerel Fishery, Fish. Res., 50, 163-171, 2001.

Reid, P. C., Edwards, M., Beaugrand, G., Skogen, M., and Stevens, D.: Periodic Changes in the Zooplankton of the North Sea During the Twentieth Century Linked to Oceanic Inflow, Fish. Oceanogr., 12, 260-269, 2003.

Rodionov, S. N.: A Sequential Algorithm for Testing Climate Regime Shifts, Geophys. Res. Lett., 31, L09204, doi:10.1029/2004GL019448, 2004.

Rodionov, S. N.: Use of Prewhitening in Climate Regime Shift Detection, Geophys. Res. Lett., 33, L12707, doi:10.1029/2006GL025904, 2006.

Rykaczewski, R. R. and Dunne, J. P.: Enhanced Nutrient Supply to the California Current Ecosystem with Global Warming and Increased Stratification in an Earth System Model, Geophys. Res. Lett., 37, L21606, doi:10.1029/2010GL045019, 2010.

Shurin, J. B., Borer, E. T., Seabloom, E. W., Anderson, K., Blanchette, C., Broitman, B., Cooper, S. D., and Halpern, B. S.: A Cross-Ecosystem Comparison of the Strength of Trophic Cascades, Ecol. Lett., 5, 785-791, 2002.

Siokou-Frangou, I., Christaki, U., Mazzocchi, M. G., Montresor, M., Ribera d'Alcalá, M., Vaqué, D., and Zingone, A.: Plankton in the open Mediterranean Sea: a review, Biogeosciences, 7, 1543-1586, doi:10.5194/bg-7-1543-2010, 2010.
Skliris, N., Elkalay, K., Goffart, A., Frangoulis, C., and Hecq, J. H.: One-Dimensional Modelling of the Plankton Ecosystem of the North-Western Corsican Coastal Area in Relation to Meteorological Constraints, J. Marine Syst., 27, 337-362, 2001.

Skliris, N., Sofianos, S., and Lascaratos, A.: Hydrological Changes in the Mediterranean Sea in Relation to Changes in the Freshwater Budget: a Numerical Modelling Study, J. Marine Syst., 65, 400-416, 2007.

Sommer, U.: Trophic Cascades in Marine and Freshwater Plankton, Int. Rev. Hydrobiol., 93, 506-516, 2008.

Sommer, U. and Sommer, F.: Cladocerans versus Copepods: the Cause of Contrasting Top-Down Controls on Freshwater and Marine Phytoplankton, Oecologia, 147, 183-194, 2006.

Stemmann, L., Prieur, L., Legendre, L., Taupier-Letage, I., Picheral, M., Guidi, L., and Gorsky, G.: Effects of Frontal Processes on Marine Aggregate Dynamics and Fluxes: an Interannual Study in a Permanent Geostrophic Front (NW Mediterranean), J. Marine Syst., 70, 1-20, 2008.

Strickland, J. D. H. and Parsons, T. R.: A Practical Handbook of Seawater Analysis, Queen's Printer, Ottawa, 1977.

Taylor, A. H., Allen, J. I., and Clark, P. A.: Extraction of a Weak Climatic Signal By an Ecosystem, Nature, 416, 629-632, 2002.

Vandromme, P.: Decadal Evolution of the Ligurian Sea Zooplankton Linked to Environmental Fluctuations. From Imaging Systems to Size-Based Models, Ph.D. thesis, University Pierre \& Marie Curie - Paris VI, 2010.

Vargas-Yanez, M., Zunino, P., Benali, A., Delpy, M., Pastre, F., Moya, F., Garcia-Martinez, M. D., and Tel, E.: How Much Is the Western Mediterranean Really Warming and Salting?, J. Geophys. Res.-Oceans, 115, C04001, doi:10.1029/2009JC005816, 2010.

Wiltshire, K. H., Malzahn, A. M., Wirtz, K., Greve, W., Janisch, S., Mangelsdorf, P., Manly, B. F. J., and Boersma, M.: Resilience of North Sea Phytoplankton Spring Bloom Dynamics: an Analysis of Long-Term Data at Helgoland Roads, Limnol. Oceanogr., 53, 1294-1302, 2008.

Zhou, M., Carlotti, F., and Zhu, Y.: A Size-Spectrum Zooplankton Closure Model for Ecosystem Modelling, J. Plankton Res., 32, 1147-1165, 2010. 